\title{
Present State of Pasture Types of the Central Kyzylkum
}

\author{
Adilov Bekhzod1, Rakhimova Tashkhonim1, Rakhimova Nodira1, Alimova Rano², \\ Sagdiev Mirqosim², Vakhidov Yusuf ${ }^{3}$ \\ ${ }^{1}$ Institute of Gene Pool of Plants and Animals AS RUz, Tashkent, Uzbekistan \\ ${ }^{2}$ Tashkent State Agrarian University, Tashkent, Uzbekistan \\ ${ }^{3}$ Unitary Enterprise Geoinform Cadastre of Uzbekistan, Tashkent, Uzbekistan \\ Email: bekhzod_a@mail.ru
}

Received 21 January 2016; accepted 27 March 2016; published 30 March 2016

Copyright (C) 2016 by authors and Scientific Research Publishing Inc.

This work is licensed under the Creative Commons Attribution International License (CC BY). http://creativecommons.org/licenses/by/4.0/

(c) (i) Open Access

\section{Abstract}

The modern state of desert pastures of the Central Kyzylkum has been studied. The pasture territories of the Central Kyzylkum are distributed on sandy soils (14\%), salt marshes (6\%), gravellyloamy gray-brown soils $(75 \%)$ and riparian nature-territorial complexes $(5 \%)$. The main $(75 \%)$ areas of pasture are occupied by the gravelly-loamy gray-brown soils which are dominated by species of sagebrushes. There are formed of 8 pasture types depending on the properties of natural complexes. The main type of pasture is sagebrushes (Mixto artemisieta), which occupy $60 \%$ of the pasture area, and then follow Peganeta harmala, Mixto calligoneta, Halocnemeta strobilacei, Tamariceta varia, Haloxyleta aphylli, Convolvuleta hamadae and Mixshrubs pasture types. The share of fodder plants is high (an average of 83\%) in the flora of the study area. According to seasonal grazing, pastures of the Central Kyzylkum can be divided 5 groups: year-round, spring, spring-summer, autumn-winter and unsuitable pastures for grazing. Among them are prevail year-round grazing pastures. The numbers of annual plants and abundance venomous plants in the flora are indicators of pasture degradation in the study area. Annual plants may occupy 55\% of composition of plant communities on degraded sites, besides the pasture types which formed under the influence of anthropogenic factors. In Central Kyzylkum newly formed and transformed pasture types occupy $25 \%$ of pastures.

\section{Keywords}

Types of Pasture, Venomous Plants, Productivity, Seasonal Use, Degradation Indicators

\section{Introduction}

Extensive natural desert pastures are main area of development in the Union of Independent States (UIS) coun-

How to cite this paper: Bekhzod, A., Tashkhonim, R., Nodira, R., Rano, A., Mirqosim, S. and Yusuf, V. (2016) Present State of Pasture Types of the Central Kyzylkum. American Journal of Plant Sciences, 7, 677-683.

http://dx.doi.org/10.4236/ajps.2016.74060 
tries as less labor intensive and more profitable livestock industry. The potential for further development of sheep and camel in desert pastures is of enormous importance.

The total area of desert pastures in the Union of Independent States (UIS) is about 180 million hectares and is used all year round thanks to the presence of natural fodder. The desert region of the UIS is grazing more than 17 million karakul sheep and goats. Natural desert pastures in Turkmenistan are 95\% and Kazakhstan-89\% of the total agricultural land. This figure is $84 \%$ in Uzbekistan and its territory is fully located on the territory of the Kyzylkum desert [1] [2]. In the countries of Central Asia, the Kyzylkum desert provides valuable forage for livestock. The flora Kyzylkum is estimated about 1050 species and the fodder flora consists of no less than 908 species (86\%) [3] [4].

At the same time the Central Kyzylkum, located on the territory of the Republic of Uzbekistan, is of great importance to maintain the well-being of a million people in the desert zones and economic development of the county. Production of all types of cattle products is concentrated in this region, but it is an independent geobotany district, where, unfortunately, there are no data on its pastoral response.

One of the quality indicators of the Central Kyzylkum pastures is to spread sagebrush species which is important to maintain quality karakul fur and a healthy livestock [5]. Reducing the proportion of pasture lands of the Central Kyzylkum and sharp increase in the number of farm animals for the last 20 years has taken the negative consequences, especially on the quality of sagebrush pastures [5] [6]. In addition, the cutting forage shrubs, various anthropogenic impacts during the construction of linear structures and geological exploration have their negative impact on the pasture ecosystems of the research area. Unfortunately, to date, the degree of degradation by overgrazing of the vegetation cover of the Central Kyzylkum is 35.7\% [2] [7].

This paper presents the current state of pastures of the Central Kyzylkum, the characteristic of pasture types and shows indicators degradation.

\section{Materials and Methods}

Central Kyzylkum includes several remote mountains that cover the northern, southwestern and south-eastern district of Kyzylkum [8] and is located within two administrative regions (Bukhara, Navoi) of Uzbekistan.

In the Central Kyzylkum, the total solar radiation reaches $140-160 \mathrm{kcal} / \mathrm{cm}^{2}$ per year, and the radiation balance is up to 50 - 60 (sometimes up to 70) $\mathrm{kcal} / \mathrm{cm}^{2}$ per year. The duration of sunshine is high, $2500-3000 \mathrm{~h}$ per year. The sum of temperatures above $10^{\circ} \mathrm{C}$ is $4000^{\circ}-5000^{\circ}$ and higher. The average annual temperature is about $16^{\circ} \mathrm{C}$, the average temperature in January is $0^{\circ} \mathrm{C}-10^{\circ} \mathrm{C}$. The duration of the growing season is $240-260$ days. The bulk of the precipitation falls in winter-spring and partly in the autumn period (the maximum is observed from December to April). The annual precipitation is $70-125 \mathrm{~mm}$. There is almost no precipitation in the summer [9].

The research was conducted in the largest and most anthropogenic-dynamic territory of the Central Kyzylkum—on the massif of "Kokcha". It includes remote mountain Kokchatau, massif area-341,521 hectares, of which $89 \%$ (304,806 ha) are pasture.

Defining pasture differences was conducted identifying the dominant plant species. Vegetation cover and forage yields were determined among pasture types by transect $(10 \times 2 \mathrm{~m})$ and mowing areas $(1 \times 1 \mathrm{~m})$. The degree of plant abundance on the vegetation is determined on the 7-point scale and given by the following notation: $5 \%-10 \%$-sol, $10 \%-20 \%-\mathrm{sp}_{1}, 20 \%-40 \%-\mathrm{sp}_{2}, 40 \%-50 \%-\mathrm{sp}_{3}, 50 \%-70 \%-\mathrm{cop}_{1}, 70 \%-80 \%-\mathrm{cop}_{2}, 80 \%$ $-90 \%-\mathrm{Cop}_{3}[10]$.

Pasture types and difference corrected by the explication of vegetation Uzbekistan [11].

The Latin name of the plant species is given by Cherepanov [12], the name of pasture types by Rabotnov [13].

\section{Results and Discussion}

\subsection{The Pasture Flora and Distribution of Pastures}

Fodder flora of Kyzylkum desert consists of 908 species of vascular plants belonging to 345 genera and 68 families. In the fodder flora of Kyzylkum is dominated by annuals (1/2 of all taxa), the share perennials estimated 283 types (31.1\%), and tree and shrubs are not more than 166 species (12.7\%) [3] [4].

According to our data, in the study area recorded 229 plant species of belonging to 144 genera and 40 families. Of these, 218 species are fodder. The pasture flora is dominated by species of the family Chenopodiaceae, As- 
teraceae, Fabaceae, Brassicaceae, Boraginaceae, Poacea, Ranunculaceae, Lamiaceae, Liliaceae and Caryophyllaceae. The analysis of the distribution of plant species showed that annual species were dominant followed by perennials. Share of trees and shrubs do not exceed of $20.0 \%$.

The pasture territories of the Central Kyzylkum are distributed on sandy soils (14\%), salt marshes (6\%) and riparian nature-territorial complexes (5\%). The main (75\%) areas of pasture are occupied the gravelly-loamy gray-brown soils which are dominated by species of sagebrushes (Artemisia diffusa, A. turanica) (Table 1).

Gray-brown soils wide spread in the southern and central parts of the Kyzylkum. In the Central Kyzylkum gray-brown soils are covered with sand "cloak", which is a determining factor in the formation of vegetation in this region [8]. 50\% - 60\% of the soil is consisted of gravel with a length of $7-10 \mathrm{~mm}$. The area of salt marshes and riparian forests is low (5\% - 6\%) and they are considered as a new map-units, which are not registered in the reference map of the study area in 1995 year.

\subsection{Characteristics of Pasture Types}

There are formed of 8 pasture types depending on the properties of natural complexes. The main type of pasture is sagebrushes (Mixto artemisieta), which occupy $60 \%$ of the pasture area. Then follow Peganeta harmala (13\%), Mixto calligoneta (7\%), Halocnemeta strobilacei (6\%), Tamariceta varia (5\%), Haloxyleta aphylli (5\%), Convolvuleta hamadae (2\%) and Mixshrubs (2\%) pasture types (Table 2).

It spread 39 species of Artemisia on the territory of Uzbekistan and is mainly participated Northern-Turan species of sagebrushes-Artemisia diffusa, A. turanica in the formation of the Central Kyzylkum vegetation [5] [14]. Also, in the Central Kyzylkum 60\% of the pasture area is refers to a type of Mixto artemisieta which dominated by sagebrush species-Artemisia diffusa, A. turanica (Table 2). The cover vegetation is $54 \%$ and rich in species composition (83 plant species). The proportion of forage plants is $85 \%$. The average seasonal yield is $330 \mathrm{~kg}$ per hectare. Due to the abundance of different kinds of vital forms and eaten plants, this pasture is considered a year-round pasture for seasonal use. Dominants of the pasture type Artemisia diffusa, Artemisia turanica are a valuable fodder plants for a sheep, goats and camels. Eaten features of the aboveground annual phytomass are persisted on $80 \%$ for all season. In addition, the species composition is rich of following valuable

Table 1. The distribution of pastures in different natural-territorial complexes.

\begin{tabular}{ccc}
\hline Natural-territorial complexes & \multicolumn{2}{c}{ Area } \\
\cline { 2 - 3 } Gravelly-loamy gray-brown soils & ha & 75 \\
Sandy soils & 228,247 & 14 \\
Salt marshes & 42,977 & 6 \\
Riparian forests & 17,940 & 5 \\
\hline
\end{tabular}

Table 2. Characteristic pasture types of the Central Kyzylkum.

\begin{tabular}{|c|c|c|c|c|c|}
\hline \multirow[t]{2}{*}{ Pasture types } & \multirow{2}{*}{ Soil types } & $\begin{array}{l}\text { Vegetation } \\
\text { cover }\end{array}$ & $\begin{array}{l}\text { Annual seasonal } \\
\text { yield }\end{array}$ & $\begin{array}{l}\text { The proportion of } \\
\text { forage plants }\end{array}$ & Area \\
\hline & & $\%$ & $\mathrm{~kg}$ & $\%$ & $\mathrm{~km}^{2}$ \\
\hline $\begin{array}{l}\text { Mixto artemisieta } \\
\text { of them a plant communities on degraded areas }\end{array}$ & Sandy gray-brown & $\begin{array}{l}52 \\
35\end{array}$ & $\begin{array}{l}330 \\
130\end{array}$ & $\begin{array}{l}85 \\
38\end{array}$ & $\begin{array}{c}183,555 \\
2301\end{array}$ \\
\hline Convolvuleta hamadae & Sandy & 55 & 310 & 82 & 6723 \\
\hline Mixto calligoneta & Sandy & 45 & 440 & 79 & 21,778 \\
\hline Tamariceta varia & Salt marsh & 65 & 390 & 87 & 15,642 \\
\hline Mixshrub & Sandy & 45 & 330 & 81 & 6668 \\
\hline Halocnemeta strobilaceae & Salt marsh & 15 & 52 & 100 & 17,940 \\
\hline $\begin{array}{l}\text { Haloxyleta aphyllai } \\
\text { of them a plant communities on degraded areas }\end{array}$ & Sandy & $\begin{array}{l}55 \\
35\end{array}$ & $\begin{array}{l}400 \\
110\end{array}$ & $\begin{array}{l}82 \\
48\end{array}$ & $\begin{array}{c}14,531 \\
5486\end{array}$ \\
\hline Peganeta harmala & Sandy gray-brown & 45 & 180 & 71 & 37,969 \\
\hline
\end{tabular}


fodder ephemera and ephemerides Carex pachystylis, Poa bulbosa, Koelpinia linearis, Eremopyrum buonapartis, Strigosella africana.

The Convolvuleta hamadae pasture type takes $2 \%$ of the study area. The vegetation cover is $55 \%$, only 46 species are found. Dominant plants Convolvulus hamadae spreads with the abundance of $\mathrm{sp}_{3}$. The average seasonal yield is $310 \mathrm{~kg}$ per hectare. The proportion of forage plants is $82 \%$. Dominant plants Convolvulus hamadae refers to a group of low-eaten plants. However, this pasture type is considered a spring pasture for seasonal use, since the spring is formed $85 \%$ of the crop phytomass and this is due to the formation of a large biomass by Carex physodes, Poa bulbosa and Astragalus villosissimus.

Calligonum determines the landscape of sandy desert zone of the Central Kyzylkum. Mixto calligoneta pasture type occupies $7.1 \%$ of the total pasture area of the research massif $\left(21.778 \mathrm{~km}^{2}\right)$. Pasture type is rich in species composition, only 52 species are found, of these shrubs and trees— 5 , semishrubs - 4, perennial grasses-15, annuals-28. The vegetation is rich in such dominant fodder plants as Calligonum microcarpum $\left(\mathrm{sp}_{3}\right.$-cop $\left.{ }_{1}\right)$, Calligonum leucocladum $\left(\mathrm{sp}_{3}-\mathrm{cop}_{1}\right)$, Artemisia diffusa $\left(\mathrm{sp}_{2}-\mathrm{sp}_{3}\right)$, Carex physodes $\left(\mathrm{sp}_{1}-\mathrm{sp}_{3}\right)$, Poa bulbosa $\left(\mathrm{sp}_{1}-\mathrm{sp}_{2}\right)$. Mixto calligoneta pasture type is the highest in terms of yield, since the seasonal average yield of $440 \mathrm{~kg}$ per hectare. The proportion of forage plants is $79 \%$. This pasture is considered optimal for grazing for the whole season, due to the abundance produced above-ground crop mass of dominant plants. One of the features of this pasture type is to inclusion eco-plastic annual halophytes in sand depressions such as Ceratocarpus utriculosus, Girgensohnia oppositiflora, Salsola iberica, Salsola sclerantha $\left(\mathrm{sp}_{1}-\mathrm{sp}_{3}\right)$, which is an indicator of beginning of overgrazing.

Natural and historical formation of the riparian forest tracts in the Kyzylkum are only preserved in the valley of the Amudarya, Syrdarya and Zarafshan. With geological and geographical point of view, formation of riparian forest tracts is due only to those habitats that are dominated by alluvial hydromorphic soils. However, there has been the emergence and expansion of territories riparian forests even the salt marshes at negative human activities in the Central Kyzylkum. Wherein, Tamariceta varia pasture type relates to a new natural-territorial complex-riparian forests. In the study area the appearance of the reservoir "Shurkul" and collector lake "Agitma" contributed to the formation of pasture type. It takes of $5 \%$ the pasture area and distributes in the salt marshes and hilly sands. The vegetation cover is large-65\%. Pasture type formed by riparian forest species Tamarix hispida, T. laxa $\left(\mathrm{sp}_{2}-\mathrm{cop}_{1}\right)$. The average seasonal aboveground yield is $390 \mathrm{~kg}$. The proportion of forage plants is $87 \%$. Formation general crop biomass increases on the spring (70\%) to the autumn (100\%). Eating feature of pasture biomass is $30 \%$ in spring, autumn and winter- $50 \%-60 \%$. In winter Tamariceta varia on the floristic composition is the most eaten pasture type by grazing in comparison with other pastures of the Central Kyzylkum.

The Mixshrub pasture type occupies only $2 \%$ of the pasture area of the massif. Type is distributed in hilly and plain of sandy soils, vegetation cover is $45 \%$. It formed by a variety of shrubs like Haloxylon persicum, Astragalus villosissimus, Convolvulus hamadae, Calligonum microcarpum, Lycium ruthenicum, Ammothamnus lehmanii $\left(\mathrm{sp}_{2}-\mathrm{cop}_{1}\right)$. The average seasonal yield is $330 \mathrm{~kg}$ per ha. The proportion of forage plants is $81 \%$. This pasture belongs to the group of the unsuitable pastures for grazing. The seasonal change of eating features of plants is not distributed evenly by season, which is considered a cause of unsuitable for grazing. Seasonal eaten of crop biomass does not exceed of $30 \%-45 \%$.

The greatest variety of halophyte vegetation is concentrated in the salt-marshes and lake basins in the Kyzylkum. The most widespread saline soils and alkaline lands developed under the influence of groundwater [4] [15]. The Halocnemeta strobilaceae pasture type relates to a new natural-territorial complex-salt marshes in the Central Kyzylkum. It is a type of new formed pastures under the influence of anthropogenic factors. In the Central Kyzylkum Halocnemeta strobilaceae pasture type formed on the outskirts of the reservoir "Shorkul" and networks of irrigation canals and most of the pasture (88\%) are confined to these sites. Violation of the hydrological regime of the soil in flood irrigation systems has led to soil salinization and contributed to the spread of annual halophytes. In pasture type plants unevenly distributed in small "patches", that is considered to be the cause of low crop yields. The vegetation cover does not exceed 10\% - 15\% and dominant plant Halocnemum strobilaceum - a true halophyte that can accumulate in their tissues than $25 \%$ of salts. The species composition of vegetation on the salt marsh is relatively poor-there are only 13 species, of these, 11 species are annuals. The yield is not high, the average seasonal yield of $52 \mathrm{~kg}$ per hectare. This pasture is considered the autumnwinter pasture for seasonal use. In the spring and summer the eaten crop biomass is low $10 \%$, in autumn and winter, this figure rises to $50 \%-55 \%$. 
The Haloxyleta aphyllai pasture type is characteristic type of the Central Kyzylkum desert flora. The formation of this type is mostly associated with ancient and modern valleys, with various negative elements of reliefbasins, inter-ridge depressions in the sands, where hydrological conditions are favorable for them. Pasture occupies $5 \%$ of the total pasture area. Dominant species Haloxylon aphyllum spread with the abundance of cop $_{1}$. There are 61 species: trees and shrubs -7 , semishrubs -7 , perennial grasses -22 and annuals -25 . The proportion of forage plants is $82 \%$. The average seasonal yield is of $400 \mathrm{~kg}$ per hectare. This pasture is considered the autumn-winter pasture for seasonal use. Eating feature of plants is increase from spring to winter.

In 1964 year I.I. Granitov [8] noted effect of anthropogenic pressure on sagebrushes, despite the broad liability desert environment, sagebrushes can be easily transformed with the overgrazing to plant associations are not specific for this or that region. He indicated the disappearance of the sagebrushes and the appearance of venomous and uneaten plants Goebelia pachycarpa and Peganum harmala in the Southwestern Kyzylkum. According to our observations, as a result of overgrazing and man-made effects on sagebrush pastures of the Central Kyzylkum are especially formation of Peganum harmala-Peganeta harmala pasture type. Pasture type formed near the village, the well and paddock, where the soil structure is deteriorating due to the continuous compression of the hooves of farm animals. Pasture type occupies $12 \%$ of the total pasture area and only found 48 species, including shrubs -4 , semishrubs -1 , perennial grasses -15 and annuals -28 . The proportion of forage plants is $69 \%$. The yield of pasture type is low-average seasonal yield of only $130 \mathrm{~kg}$ per hectare. This pasture is considered the spring-summer pasture for seasonal use. Eating feature of forage plants saved up to 50\% - 55\% due to the ephemeral and ephemeroids to the spring-summer season. Reduced share of ephemera and ephemeroids in autumn-winter seasons is considered to cause a sharp decrease in the degree (35\% - 40\%) of pasture use.

\subsection{The Quality and Degradation Indicators of Pastures}

The share of fodder plants is high (average of $83 \%$ ) in the composition of all pasture types, this figure is $43 \%$ in the plant communities on degraded areas (Table 2). If estimate the quality of pasture region, $67 \%$ of the areas correspond to the share of pastures which using year-round (Mixto calligoneta and Mixto artemisieta pasture types) and it is typical for the desert pastures of Central Asia (Table 3). Also there is widespread autumn-winter (14\%), spring-summer (12\%), spring (2\%) pastures. Unsuitable pastures which indicated the uneven distribution of seasonal eaten features of forage plants are occupied $2 \%$ of the pasture area. $3 \%$ of the study area is pastures with varying degrees of degradation. In these areas the abundance of uneaten and poisonous plants is high, the proportion of forage plants and annual seasonal yield are low as prevents rational provision of pasture feed farm animals.

Regular pressure on pastures, often without regard to their potential possibilities, leads to the appearance of uneaten and venomous plants, reduction of certain valuable fodder plants. The prevalence of annual plants is alarming indicator of the increasing anthropogenic pressure on the Kizilkum pasture vegetation. In addition, the increase of the abundance uneaten plants also is an indicator characterizing the degree of pasture degradation in plant communities [3] [16] [17].

According to the analysis of the flora revealed that the number of annual plants and abundance of uneaten, venomous plants are indicators of pasture degradation of the Central Kyzylkum. In particular, the vegetation those share of annual plants higher than $55 \%$ are found in plant communities on degraded areas, as well as the new formed and transformed pasture types (Table 4). The high proportion (85\%) of annual plants is found in the Halocnemeta strobilaceae pasture type. Wherein, the share of annual halophytes is $60 \%$, as indicate of high they

Table 3. The distribution of pasture types of seasonal use.

\begin{tabular}{cc}
\hline Group of seasonal use & Pasture types \\
Year-round pastures & Mixto artemisieta, Mixto calligoneta \\
Autumn-winter pastures & Tamariceta varia, Halocnemeta strobilaceae, Haloxyleta aphyllai \\
Spring-summer pastures & Peganeta harmala \\
Spring pastures & Convolvuleta hamadae \\
Unsuitable pastures & Mixshrub \\
Plant communities on degraded areas & \\
\hline
\end{tabular}


Table 4. Quantitative indicators of annual and uneaten, venomous planrs on pasture types.

\begin{tabular}{|c|c|c|c|}
\hline Pasture types & $\begin{array}{l}\text { Share of annual } \\
\text { plants } \\
\%\end{array}$ & $\begin{array}{l}\text { Share of uneaten and } \\
\text { venomous plants } \\
\%\end{array}$ & Abundance of uneaten and venomous plants \\
\hline Mixto artemisieta & 48 & 10 & Iris songarica- $\mathrm{sp}_{2}$ \\
\hline $\begin{array}{c}\text { Of them a plant communities on } \\
\text { degraded areas }\end{array}$ & 61 & 9 & $\begin{array}{l}\text { Nitraria shoberi- } \mathrm{cop}_{1} ; \text { Iris songarica }-\mathrm{sp}_{3} ; \text { Goebelia } \\
\text { pachycarpa }-\mathrm{sp}_{2} ; \text { Tortula desertorum- } \mathrm{sp}_{2} .\end{array}$ \\
\hline Convolvuleta hamadae & 37 & 7 & Iris songarica- $\mathrm{sp}_{2}$ \\
\hline Mixto calligoneta & 52 & 11 & 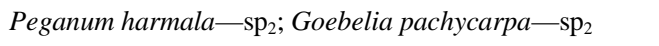 \\
\hline Tamariceta varia & 67 & 9 & $\begin{array}{l}\text { Halimodendron halodendron- } \mathrm{sp}_{3} ; \text { Nitraria shoberi- } \mathrm{sp}_{3} ; \\
\text { Peganum harmala—- } \mathrm{sp}_{2} ; \text { Lycium ruthenicum- } \mathrm{sp}_{2} .\end{array}$ \\
\hline Mixshrub & 38 & 9 & 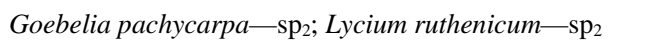 \\
\hline Halocnemeta strobilaceae & 85 & - & - \\
\hline Haloxyleta aphyllai & 41 & 10 & Lycium ruthenicum- $\mathrm{sp}_{2} ;$ Peganum harmala- $\mathrm{sp}_{2}$. \\
\hline $\begin{array}{c}\text { Of them a plant communities on } \\
\text { degraded areas }\end{array}$ & 58 & 10 & 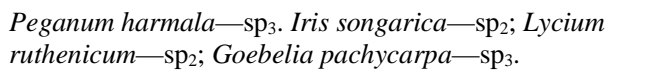 \\
\hline Peganeta harmala & 58 & 13 & $\begin{array}{l}\text { Peganum harmala- } \mathrm{sp}_{3}-\mathrm{cop}_{2} ; \text { Goebelia pachycarpa- } \mathrm{sp}_{2} ; \\
\text { Iris songarica- } \mathrm{sp}_{2} ; \text { Ceratosephalus testiculata- } \mathrm{sp}_{2} ; \\
\text { Tortula desertorum- } \mathrm{sp}_{2} ; \text { Lycium ruthenicum- } \mathrm{sp}_{2} \text {. }\end{array}$ \\
\hline
\end{tabular}

ruderal diapason [18]. The proportion of annual species is $67 \%$ in the Tamariceta varia pasture type. The formation of this type occurs on humid-saline soils, in spite of this, of the total annual plants (33 species) the proportion of annual halophytes is only $21 \%$. Other annual plants are mainly related members of the family Boraginaceae (12\%), Poaceae (9\%) and Asteraceae (9\%). Occurrence of representatives of other families that are not specific to saline hydromorphic soils is not yet complete formation of the plant community in the Tamariceta varia pasture type.

Share uneaten and venomous plants are $7 \%$ - $13 \%$ in the composition of the all pasture types of the Central Kyzylkum. However, the abundance of uneaten and venomous plants is high in the degraded areas, as well as in the new formed and transformed pasture types, which covered $40 \%-80 \%\left(\mathrm{sp}_{2}-\mathrm{Cop}_{2}\right)$ of vegetation. The halophilic flora Kizilkum are found 13 species of venomous plants [3], however, in the vegetation of the halophilic Halocnemeta strobilaceae pasture type is not observed venomous plants in the study area. As results of pasture degradation of the Central Kyzylkum, there are widespread following of the venomous and uneaten plants: $P e$ ganum harmala, Goebelia pachycarpa, Iris songarica, Ceratosephalus testiculata, Tortula desertorum, Lycium ruthenicum, Halimodendron halodendron, Nitraria shoberi.

\section{Conclusions}

The Central Kyzylkum is located in the desert region and its pasture flora is rich in forage plants. The dominance of the territory year-round pastures provides a great opportunity for the development of pasture cattle breeding.

In Central Kyzylkum, it reinforces the negative human impact on the pasture ecosystem. Its negative impact acts on two directions. First, the development of new agricultural lands as a result of human activities is considered to be the cause of the destruction of water-salt balance of the soil and increase the groundwater level. This is beneficial to the formation of new pasture types, which is not specific to the region. Second, around the settlements observed overgrazing and historical formed pastures are transformed pastures which consist of venomous plants. In Central Kyzylkum newly formed and transformed pasture types occupy 25\% of pastures. The Halocnemeta strobilacei and Tamariceta varia pasture types in the salt marshes are considered as new formed pastures or new map-units, which are not registered in the reference map of the study area in 1995. As a result of overgrazing, there is transformation of sagebrush pastures on pastures that is dominated by venomous plant $P e$ ganum harmala as an indicator of the watering presence and digression of pasture.

There is a positive side of the newly formed pasture types. The Tamariceta varia pasture type, highly productive riparian forests on the hydromorphic saline soils, is important to stabilize ecological condition and preservation of biological diversity of the region. The Halocnemeta strobilacei pasture type in the salt marsh cannot be 
considered a low of yield pastures. Cultivation halophyte plants by remediation methods can improve pasture fund territory.

\section{Acknowledgements}

The authors would like to acknowledge Ugilshod Allanazarova for his expertise and technical assistance in these studies. Funding for this project was provided by the Academy of Sciences of the Republic of Uzbekistan and the State Committee for Science and Technology.

\section{References}

[1] Penjiyev, A.M. (2013) Ecological Problems of Desert Development: Migration, Pasture Improvement and Global Land Degradation. Alternative Energy and Ecology, 14, 89-107.

[2] Yusupov, S.Yu., Rakhimov, A.R. and Mukimov, T.Kh. (2010) The Current State of Astrakhan Pastures Kyzylkum and Ways of Their Rational Use. Arid Ecosystems, 2, 38-46.

[3] Khasanov, F.O., Shomuradov, Kh.F. and Kadyrov, G. (2011) A Review and Analysis of Plant Endemism of Kyzylkum Desert Flora. Botanical Journal, 96, 237-245.

[4] Shomurodov, Kh.F. and Khasanov, F.O. (2014) Forage Plants Kyzylkum Desert. Arid Ecosystems, 3, 94-101.

[5] Rakhimova, T. (2010) Sagebrushes of the Kokchatau. Biological Journal of Uzbekistan, 5, 28-30.

[6] (2010) Cattle in Uzbekistan: Current State and Problems (UNDP Program). Nasaf, 2010, 154.

[7] Rajabov, T.F., Mardonov, B.K., Nasyrov, M.G., Muminov, M.A. and Mukimov, T.X. (2010) Application of Remote Sensing and Geographical Information Systems for Rangeland Monitoring in Uzbekistan. Journal of Environmental Science and Engineering, 6, 78-82.

[8] Granitev, I.I. (1964) The Vegetation Cover South-West Kyzylkum. Tashkent, Science, 335.

[9] Rachkovskaya, E.I., Safronova, I.N. and Volkova, E.A. (2003) Botanical Geography of the Desert Area of Kazakhstan and Central Asia. Biol. Inst., St. Petersburg, 192-222.

[10] (1980) Guidelines for Geobotanical Investigation of Natural Grassland in Uzbekistan. Tashkent, Science, 170.

[11] (1965) Legend and Symbols to the Vegetation Map of Uzbekistan. Tashkent, Science, 66.

[12] Czerepanov, S.K. (1995) Vascular Plants of Russia and Adjacent States (the Former USSR). Cambridge University Press, Cambridge, 516.

[13] Rabotnov, T.A. (1987) Experimental Phytosociology. University Press, Moscow, 220.

[14] Kapustina, L.A., Torrel, M. and Valles, J. (2001) Artemisia Communities in Arid Zones of Uzbekistan (Central Asia). USDA Forest Servise Proceedings RMRS-P-21, 2001.

[15] Akzhigitova, N.I. (1982) Halophytic Vegetation in Central Asia and Its Indicative Properties. Tashkent, Fan, 189.

[16] Ryabinina, Z.N. (2003) The Vegetation Covers of the Steppes of the Southern Ural. Orenburg, OGPU, 233.

[17] Ayusheva, E.Ch. (2014) Vegetation Dynamics of Phyto Eclaimed Land in the Desert Zone of Kalmykia. Abstract of Dissertation for the Degree of Candidate of Biological Sciences (PhD). Saratov, 20.

[18] Ramenskii, L. (1938) Introduction to Complex Soil-Geobotanical Study of Land. Moscow, Selkhozgiz, 629. 